\title{
REVIEW
}

\section{Airway smooth muscle cell culture: application to studies of airway wall remodelling and phenotype plasticity in asthma}

\author{
S.J. Hirst
}

\begin{abstract}
Airway smooth muscle cell culture: application to studies of airway wall remodelling and phenotype plasticity in asthma. S.J. Hirst. (C)ERS Journals Ltd 1996.

ABSTRACT: Chronic persistent asthma is characterized by poorly reversible airway obstruction. Histopathological studies of airways removed postmortem from patients with severe asthma reveal marked inflammatory and architectural changes associated with airway wall thickening. Increased airway smooth muscle content, occurring as a result of hyperplastic and/or hypertrophic growth, is believed to be one of the principal contributors to airway wall thickening. Intense interest is building to discover the mechanisms responsible for these long-term structural changes.

In vitro cell culture offers a powerful and exacting approach to cellular and molecular studies of the long-term regulation of airway smooth muscle function. This review discusses the methodologies for establishing and maintaining cell cultures of airway smooth muscle. It also describes the characteristics of these cells in culture and addresses the potential importance of phenotype plasticity and its possible relationship to altered smooth muscle function in vivo. Drawing on parallels from vascular studies, this review focuses, in particular, on the synthetic nature of the airway smooth muscle cell, emphasizing its potential to alter the composition of the extracellular matrix environment and orchestrate key events in the process of chronic airway remodelling.

Eur Respir J., 1996, 9, 808-820.
\end{abstract}

Correspondence: S.J. Hirst

Respiratory Research Laboratories

UMDS Dept of Allergy and Respiratory

Medicine

St. Thomas' Hospital

Lambeth Palace Road

London SE1 7EH

UK

Keywords: Airway smooth muscle

asthma

cell culture

extracellular matrix

phenotype

remodelling

Received: October 61995

Accepted after revision December 201995

\section{Airway wall remodelling and inflammation}

Acute and delayed onset asthma is characterized by mild inflammation, in which there is reversible airway narrowing due to excessive bronchoconstriction, airway wall oedema, epithelial cell damage, infiltration of leucocytes (mainly eosinophils), mucous plugging and stimulation of neural reflexes $[1,2]$. In chronic severe asthma, the extent of the airway wall inflammation is much more intense resulting in structural changes to the airway wall, characterized by basement membrane thickening, associated with matrix deposition, together with increased mural smooth muscle content [3-7]. These remodelling processes appear to be central to the development of poorly reversible airway obstruction and continued persistent nonspecific bronchial hyperresponsiveness $[1,2,7]$.

Data from clinical studies suggest that patients with persistent severe asthma develop irreversible airflow obstruction that is refractory to current bronchodilator and anti-inflammatory strategies [8,9]. Even prolonged administration of high doses of inhaled glucocorticoids does not redress the underlying airway hyperreactivity in these asthmatics [9]. Observations such as this imply a persistent component to the long-term pathology of asthma, which, once established, is difficult to reverse using conventional anti-asthma drugs. The persistent nature of these changes reflects remodelling or architectural changes to the airway wall which ultimately result in increases in luminal narrowing for a fixed proportion of smooth muscle shortening. HoGg and co-workers [10-12] have hypothesized that nonspecific bronchial hyperresponsiveness can be explained by any process which results in a net geometric thickening of the airway wall. Furthermore, studies using detailed computer models of human airways indicate that increased airway smooth muscle mass is by far the most important abnormality responsible for excessive airway lumen narrowing and increased compliance of the airway wall in severe asthma [13, 14]. Both hyperplastic (i.e. increases in cell number) and hypertrophic (i.e. increases in cell size) changes contribute to the increased smooth muscle content of the airway wall [15], but there is relatively little information available about the mechanisms which underlie the remodelling process. Structural changes, in which there is increased adventitial thickening of the airway wall, may also lead to excessive luminal narrowing following smooth muscle activation by uncoupling of the restraining forces usually exerted by the surrounding parenchyma, which are transduced through the alveolar septae to the airway wall and act to keep the airway open [16].

Until very recently, many studies of altered airway smooth muscle function in vitro have employed isolated muscle strips resected from the trachea or bronchi of experimental animals, which have been manipulated to mimic particular features of the pathogenesis of asthma (e.g. allergen-induced immediate and delayed airway 
obstruction, or ozone-induced bronchial hyperresponsiveness). Such studies are often limited to measurements of acute events, such as contraction, and have led to conflicting reports of increased smooth muscle contractility in asthma. The establishment and characterization of airway smooth muscle cells in culture, particularly from healthy human airways, has for the first time allowed pulmonologists to design experiments with the aim of understanding the regulation of more long-term cell responses, particularly the control of cellular growth and division. In the last 5 years, this in vitro approach has increasingly been adopted for molecular and cellular studies of both acute and long-term responses. Data from these studies are now being applied to studies of the processes which in vivo may contribute to chronic airway inflammation at the level of the smooth muscle. The significance of these studies undoubtedly lies in identifying new therapeutic strategies for controlling the chronic progression of asthma and the development of drugs with disease-modifying properties.

In this review, in light of the growing interest in the role of airway smooth muscle remodelling in chronic asthma, some of the methods for the successful maintenance and characterization of these cells in culture are discussed, as well as the proinflammatory stimuli reported to promote airway smooth muscle growth and division, and the potential significance of altered smooth muscle phenotype in the chronic remodelling process. The purpose of this review is not to present an in-depth description of the factors or their receptors and signal transduction pathways mediating airway smooth cell mitogenesis, but to emphasize the capacity of altered smooth muscle phenotype, particularly its synthetic nature, to contribute to the underlying pathology of the inflamed airway during chronic severe asthma.

\section{Airway smooth muscle thickening}

Although bronchial smooth muscle thickening is a well-documented pathological feature of the airways of patients with persistent severe asthma, there are only a handful of reports in the literature identifying its anatomical site and the extent to which hyperplasia and hypertrophy contribute to the increase in muscle mass. The techniques available for quantifying this muscle thickening can loosely be divided into in situ studies, involving morphometric analysis of the bronchial tree from normal and asthmatic patients [3-7], and studies employing cell culture techniques [17-20] as an in vitro model of the smooth muscle present in the intact airway wall.

\section{Morphometric analysis}

Several early studies have quantified bronchial smooth muscle thickening in obstructive airway disease by projecting the image of stained (usually with haematoxylin and eosin) semi-serial sections of bronchus onto a screen with a point-counting grid [3-5]. Areas of the image positively identified as smooth muscle were counted and this process was then repeated for each histological section, allowing a profile of smooth muscle thickening to be constructed over several hundred serial sections.
The results of these initial studies have achieved little other than to demonstrate the existence of smooth muscle thickening in the asthmatic airway. However, in one study by Heard and Hossain [4], the nuclei of muscle cells were also counted; and the number was found to correlate well with the increase in muscle area, suggesting that the thickening in asthma was due to hyperplasia rather than to hypertrophy.

In recent studies using a more refined three-dimensional morphometric approach [10-12, 15, 21], the image was projected onto a computer-assisted graphics tablet or a digital image analyser, allowing the bronchial crosssectional image to be "stretched" into a uniform circle without changing the overall perimeter of the basement membrane of the section or the overall sectional area of the muscle. This has the advantage, unlike the previous techniques, of standardizing the size of the airway, thereby reducing the difficulty in assessing muscle thickening in sections in which the state of muscle contraction at the time of fixation is unknown (contracted muscle might show an apparent thickening over relaxed muscle) $[6,12,15]$. Results of these latter studies confirm the presence of airway smooth muscle thickening in asthma, particularly in smaller bronchi [21].

EBINA and co-workers [6] initially reported that asthmatics exhibited thickening throughout the entire range of the bronchial tree, including the smaller airways; the latter believed to be the site of immunologically-released mediators and growth factors $[1,2,22]$. In a subsequent study, EBINA and co-workers [15] reported at least two patterns of smooth muscle thickening in the lungs of patients with severe recurrent asthma, described as types I and II. In type I asthmatics, the increase in muscle area was associated with hyperplasia of airway smooth muscle cells and was restricted to the large central airways. No hypertrophy was recorded at any level of the bronchial tree in these patients. In type II asthmatics, however, in addition to the presence of comparatively mild hyperplasia in the larger airways, hypertrophy of airway smooth muscle cells was detected throughout the whole bronchial tree, but was particularly severe in small peripheral airways. These apparently different patterns of airway wall thickening may reflect differing pathogeneses in asthma, or fundamental differences in the growth-promoting mechanisms or stimuli predominating at the smooth muscle at differing levels of the bronchial tree.

\section{Cell culture}

Although morphometric analysis undoubtedly provides valuable information about the anatomical site and severity of airway wall thickening in asthma it does not easily lend itself to the direct investigation of controlled exposure of the smooth muscle layers to mitogenic stimuli. Similarly, airway smooth muscle preparations exvivo, which have limited viability under noncultured conditions, make studies of long-term regulation of the airways, such as proliferative changes, extremely difficult to perform. The technique of cell culture, however, offers a more powerful and exacting approach to understanding the cellular and molecular mechanisms of airway smooth muscle growth and division. Indeed, this in vitro technique has been heavily exploited in recent 
years for the study of other proliferative disorders, such as cancer and atherosclerosis. Cell culture has the obvious advantage of allowing longer-term studies on regulation of airway smooth muscle growth and division in response to defined stimuli, which would be otherwise impossible. It can also overcome the problem of obtaining adequate amounts of normal tissue from human airways, where the majority of tissue obtained from surgery is often diseased.

\section{The airway smooth muscle cell in culture}

Despite widespread use of cultured vascular smooth muscle [23, 24], experience in the cultivation of smooth muscle from the airway wall was, until recently, much more limited. This probably stems from concern about the validity of such a preparation for use in pharmacological studies as a relevant model of the intact tissue [25], and whether the morphological features of such cells in culture are shared with connective tissue cells, such as fibroblasts or other nonmuscle cells [26]. This is compounded by modulations in phenotype, which may result in the loss of critical features of the differentiated cell. However, with the increasing realization of the role of smooth muscle in airway wall thickening and subsequent development of bronchial hyperresponsiveness, various groups have succeeded in culturing airway smooth muscle cells from a number of species, such as canine [17, 18, 27, 28], bovine [29-31], rabbit [32-34], guinea-pig [35, 36], sheep [37], and human [19, 20, 38-42]. Although many of these initial concerns have been largely overcome, it remains essential to characterize fully the properties of these cells and to make comparisons where possible with the intact tissue.

\section{Cultivation}

There are essentially three methods which have been employed for successfully establishing and maintaining airway smooth muscle cells in culture. These are: 1) enzymatic dispersion of smooth muscle cells from tracheobronchial muscle; 2) explant culture from cubes of muscle cut from the intact tissue; and 3) subculture passaging.

Enzymatic dispersion is the technique adopted by most investigators to obtain primary cultures of airway smooth muscle cells from a carefully dissected preparation of large or small airway $[17,19]$. This method is used to obtain isolated smooth muscle cells in a morphologically well-differentiated and contractile state [23, 24], where the immediate cellular environment may be rigorously controlled, especially when determining the effects of soluble or insoluble factors on cellular phenotype. The proteolytic regimens used by most investigators include collagenase (type IV or XI) and elastase (type I), necessitated by the high collagen and elastin content of the airway smooth muscle associated matrix. Other enzymes, such as papain, which exhibit relatively nonspecific proteolytic activities can be substituted for elastase. We have used this latter protocol for dispersion of single cells from human bronchial smooth muscle for electrophysiological recordings [42]. Alternatively, small explants of dissected smooth muscle can be used to generate primary cultures [39, 40]. Cells from explant culture, however, must inherently undergo many more population doublings in order to migrate out from the explant and proliferate throughout the culture dish. Although no systematic study appears to have been carried out, cells from explants may be less contractile, as has been reported for vascular smooth muscle cultures [24]. Whether this makes explant cultures more or less suitable for studies of airway smooth muscle remodelling has not been debated, but considerations such as these may be appropriate when considering the type of study intended. A detailed description of both these protocols for establishing airway smooth muscle cells in primary culture appears in table 1 .

Once the cells are established in culture and have grown to confluence they can be removed from their growth support, either by scraping or by treatment with trypsin in a low calcium and magnesium ion buffer, and reseeded at a subconfluent cell density and allowed to proliferate once again. Other nonenzyme based, low calcium, cell dissociation buffers can also be used to detach airway smooth muscle cells in culture from their growth support. The process of subculture passaging can be repeated several times to generate larger numbers of cells, often necessary for biochemical and molecular analyses, over a period of several months. A more detailed account of these culture methods can also be found in CAMPBELL and CAMPBELl [24].

Success in obtaining viable primary cultures of airway smooth muscle cells is critically dependent upon two factors. These are the time elapsed from excision of the tissue to its culture, and the care taken in dissection to obtain smooth muscle which is not contaminated by unwanted connective tissue, cartilage or overlying epithelium and submucosa. Human tissue is available from heart-lung transplant recipients, at postmortem [20, $39]$, or at thoracotomy [19, 32, 38, 41]. Transplant tissue probably offers the best, but least accessible, source of human tissue since large amounts of smooth muscle can be obtained. The amount of tissue which can be obtained from thoracotomy, however, is often very limited and is usually only available immediately distal to the resection margin, where there is a risk of removing malignant or transformed tissue. Whether the patient has been exposed to radiotherapy during treatment should also be considered when obtaining tissue from the operating theatre for culture. Thoracotomy specimens do, however, offer an immediate and relatively frequent source of sterile and nonhypoxic tissue. Tissue obtained at postmortem is often aseptically compromised and may not be available until 24-48 h after death. Significant autolysis occurs at this time. Given the correct conditions, however, human airway smooth muscle cells can be successfully cultured using tissue from any of these sources [19, 20, 32, 38, 39, 41].

The most frequent problems encountered in preparing and maintaining primary cultures of airway smooth muscle cells relate to microbial infection of the tissue prior to culture and contamination of primary cultures with other non-muscle cell types. Infection can be overcome by collecting tissue in sterile buffered salt solution containing antimicrobial and antifungal agents, followed by extensive washing in fresh buffer together with meticulous aseptic technique (table 1). Contamination of 
Table 1. - Example of the methodology used in our laboratory to establish human airway smooth muscle cells in primary culture

1. Wash bronchial ring 4-5 times in $20 \mathrm{~mL}$ Hank's buffered salt solution (HBSS) containing antibiotics (gentamicin 50 $\mu \mathrm{g} \cdot \mathrm{mL}^{-1}$, or penicillin $\mathrm{G} 100 \mathrm{U} \cdot \mathrm{mL}^{-1}$ and streptomycin $100 \mu \mathrm{g} \cdot \mathrm{mL}^{-1}$ ) and an antifungal agent (amphotericin B $\left.1.5 \mu \mathrm{g} \cdot \mathrm{mL}^{-1}\right)$. Use of antimicrobials is dependent on conditions at tissue collection.

2. Using sterile instruments and a dissecting tray, remove adherent connective tissue from the adventitial surface. Disrupt airway epithelium by firm scraping across the luminal surface with rounded scalpel blade. Smooth muscle can then be cut away from cartilage. Dissection under a microscope is critical to obtaining relatively homogeneous preparations of smooth muscle.

3a. Explant cultures can be established by placing small cubes (approximately $1 \times 1 \times 1 \mathrm{~mm}$ ) of smooth muscle directly into prewetted culture flasks or dishes, and then covering in a minimal volume of Dulbecco's modified Eagle's medium (DMEM) supplemented with foetal calf serum $(\mathrm{FCS})(10 \% \mathrm{w} / \mathrm{v})$, sodium pyruvate $(1 \mathrm{mM})$, L-glutamate $(2 \mathrm{mM})$, nonessential amino acids (1\%) and antimicrobial agents (as above). For the first 3-4 days, add sufficient media to just cover the tissue fragments. This ensures their attachment to the growth support.

OR

3b. Dissociated cells are obtained from smooth muscle placed in HBSS containing $10 \mathrm{mg} \cdot \mathrm{mL}^{-1}$ bovine serum albumin and the enzymes collagenase (type XI, $1 \mathrm{mg} \cdot \mathrm{mL}^{-1}$ ) and elastase (type I, $3.3 \mathrm{U} \cdot \mathrm{mL}^{-1}$ ) at $37^{\circ} \mathrm{C}$ in $5 \% \mathrm{CO}_{2}$ /air initially for $30 \mathrm{~min}, \mathrm{pH}$ 7.4. Unwanted tissue can be removed by further dissection. Prolonged dissociation $(150 \mathrm{~min})$ of minced tissue $\left(1 \mathrm{~mm}^{2}\right.$ fragments) using a higher elastase content $\left(1.5 \mathrm{U} \cdot \mathrm{mL}^{-1}\right)$ yields single cells. After centrifugation $\left(100 \times \mathrm{g}, 5 \mathrm{~min}\right.$ at $\left.22^{\circ} \mathrm{C}\right)$ and washing in DMEM containing 10\% FCS, supplemented as above cells are resuspended at 50,000 per $35 \mathrm{~mm}$ dish and maintained at $37^{\circ} \mathrm{C}$ in $5 \% \mathrm{CO}_{2}$ /humidified air. Cells adhere to the plastic dish after $6-18 \mathrm{~h}$. Replace culture medium initially after 4-5 days and then every 3-4 days until confluence (10-14 days). Cells can be subcultured by scraping or by trypsin using standard cell culture techniques.

4. The purity of primary cultures and subsequent passages should be monitored at increasing confluence or at growth arrest under the light microscope and by immunodetection of contractile proteins.

primary cultures of airway smooth muscle cells by nonmuscle cell types can be more troublesome and should always be borne in mind when interpreting data. The most frequently reported cell contaminants are airway epithelial cells, microvascular and lymphatic endothelial cells and fibroblasts [17, 18]. Epithelial and endothelial cells, both cobblestone in appearance, tend not to survive after a few days in culture, and are invariably lost following passaging from primary culture ([18], and Hirst, unpublished observations). Fibroblast contamination represents a much more difficult problem since these cells cannot be readily morphologically distinguished from smooth muscle cells, particularly at low cell densities or when cells are rapidly dividing. For this reason, it is essential to assess the morphology, expression of contractile proteins and pharmacology of airway smooth muscle cells in culture.

\section{Characteristics in culture}

Airway smooth muscle cells in culture possess a number of specific features recognized to be characteristic of smooth muscle cells in general when in culture [23, 24], and which relate them to the intact tissue [17, 18, 20, 38, 43].

Light microscopy. Under the light microscope, smooth muscle cells of tracheal or bronchial origin appear flattened and ribbon- or spindle-shaped, with phase-dense cytoplasm, central oval nuclei with prominent nucleoli and dendritic cytoplasmic processes (fig. 1A); thereby, displaying features reminiscent of differentiated contractile smooth muscle cells in the intact tissue $[17,18]$. Confluent airway smooth muscle cells, like those of vascular origin, appear to be aligned in parallel so that the broad nuclear region of one cell lies adjacent to the thin cytoplasmic area of another, forming a highly contoured architecture of ridges and nodules giving a characteristic "hill and valley" appearance (fig. 1B), a property not shared by contaminating fibroblasts or other non-muscle cells $[23,24]$.

Electron microscopy. Ultrastructural examination of nearconfluent cultured tracheobronchial smooth muscle cells of either human or animal origin shows that these cells form multiple layers in which the characteristic elongated spindle shape can be clearly seen. The cells appear flattened with numerous cytoplasmic processes and an elongated oval nucleus containing little or no heterochromatin, characteristic of cells during transcription and division; whilst in the cytoplasm, organelles associated with the synthetic phenotype predominate [18, 43] (fig. 1C). Examination at higher power confirms the synthetic nature of these cells and reveals detail of the nuclear envelope. The cytoplasm contains mitochondria, highly developed Golgi cisternae and numerous profiles of rough endoplasmic reticulum (figure $1 \mathrm{C}$ and $\mathrm{D}$ ), which are frequently associated with dilated cisternae [43] (fig. 1C). Myofilaments are rarely seen in synthetic smooth muscle cells during proliferation, but are present when the contractile phenotype is expressed [23, 25]. ToMMoy et al. [18] have reported similar observations under the electron microscope in tracheal smooth muscle cells cultured from adult dogs. As in vascular smooth muscle cell culture, the relative quantitative expression of many of these cytoplasmic structures in human and rabbit airway smooth muscle, and probably other species, may be critically dependent upon cell phenotype and culture conditions [44]. 

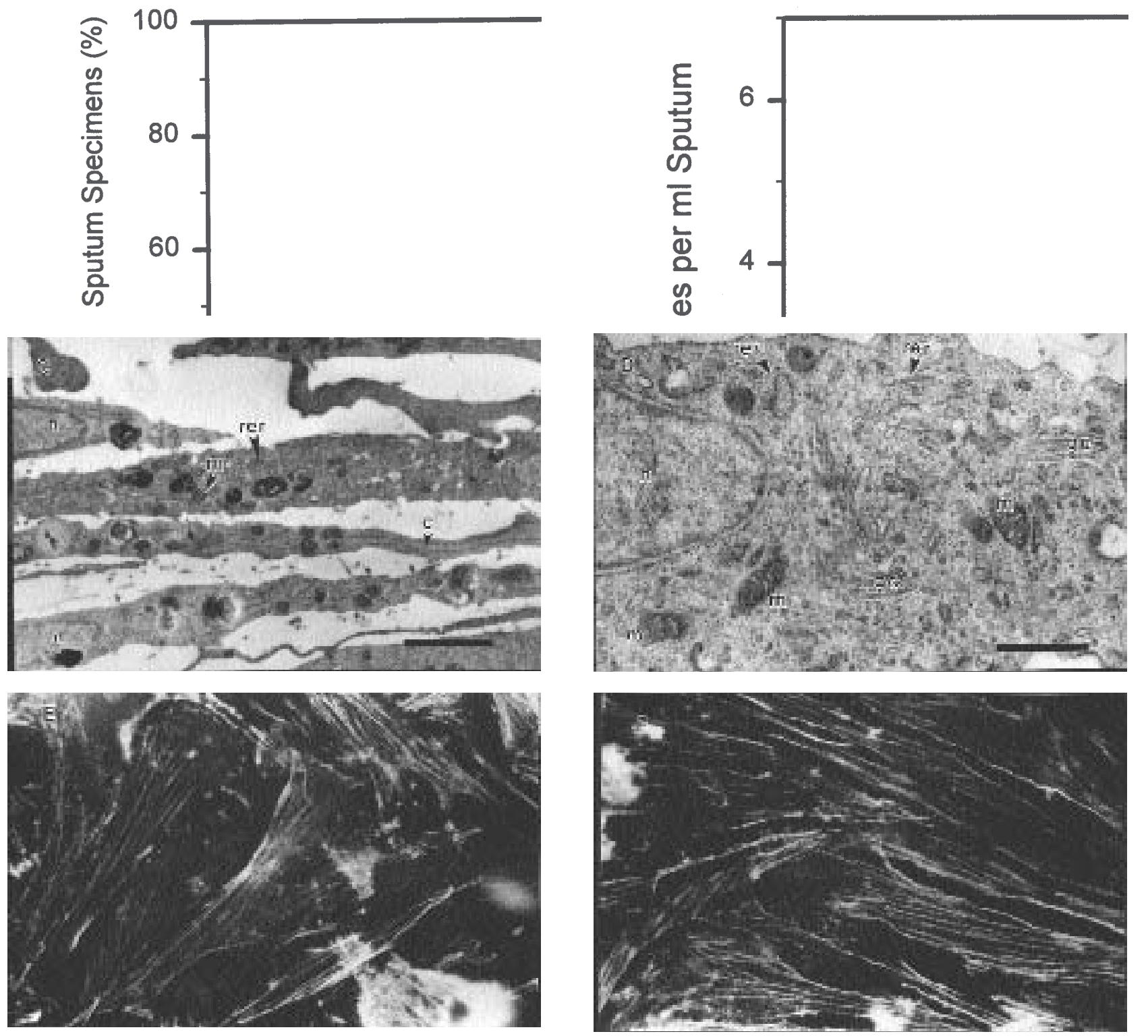

Fig. 1. - Typical appearance of: A) subconfluent; and B) confluent human bronchial smooth muscle cells in culture viewed under the light microscope using high $(A$ : internal scale bar $=10 \mu \mathrm{m})$ and low $(B$ : internal scale bar $=100 \mu \mathrm{m})$ power Nomarski differential interference contrast photomicrography. Central oval nuclei with prominent nucleoli, as well as the characteristic "hill and valley" architecture, are clearly visible. Conventional transmission electron micrographs reveal the ultrastructural detail of these cells. C) Characteristic elongated nuclei (n), as well as cytoplasmic structures, such as mitochondria (m), rough endoplasmic reticulum (rer) and dilated cisternae (c), are all clearly visible in "synthetic" phenotype proliferating cells at low power. (Internal scale bar $=2 \mu \mathrm{m}$ ). D) At higher power in proliferating cells details of mitochondria $(\mathrm{m})$, stacked Golgi cisternae (gc) and profiles of rough endoplasmic reticulum (rer) are seen. (Internal scale bar $=1 \mu \mathrm{m}$ ). Epifluorescence indirect immunostaining of smooth muscle specific contractile proteins reveals the presence of: E) actin-; and F) myosin-reactive longitudinally running parallel fibres in confluent human airway smooth muscle cells (internal scale bars $=20 \mu \mathrm{m}$ ).

Contractile protein staining. Non-muscle contaminants, such as epithelial or connective tissue cells (usually fibroblasts), can be clearly distinguished from smooth muscle cells using indirect immunofluorescent antibody staining techniques. Although fibroblasts in culture will stain weakly positive for the contractile protein, actin, it is generally accepted that only smooth muscle cells will stain for both actin and myosin using smooth musclespecific antibodies [23, 24]. An example of anti-actin $(\alpha$-chain specific) and anti-myosin (anti-SM1 and -SM2) immunostaining in confluent human bronchial smooth muscle cells is shown in figure $1 \mathrm{E}$ and $\mathrm{F}$. The pattern of staining in the cytoplasm of cultured airway smooth muscle cells both for actin and myosin reveals filamentous contractile proteins arranged in parallel to the long axis of the cells, resembling the stress fibres occasionally seen by low power electron microscopy [23]. In fibroblasts, anti-actin antibodies often reveal only diffuse cytoplasmic staining [45]. This staining technique alone is particularly useful for screening whole cultures for checks of homogeneity and purity [18, 23]. The intensity of contractile protein immunostaining, particularly smooth muscle specific myosin, declines in late passage ([20], and Hirst unpublished observations), although the total amount of actin and myosin, as in vascular smooth muscle, probably remains relatively unchanged 
due to the accumulation of non-muscle isoforms [20]. This phenomenon is well-documented in cultured vascular smooth muscle cells [23, 24, 46].

Pharmacology. One of main problems still encountered with culture of airway smooth muscle cells is loss of receptors in primary culture and a gradual decline in response during subsequent passages, probably due to modulations in phenotype during culture [18, 20, 23]. TwORT and VAN BREEMEN [19, 38] and PANETTIERI et al. [20], however, have reported the development of apparently nontransformed lines of human airway smooth muscle cells, which are relatively stable in culture over many population doublings. These cells retained smooth musclespecific contractile protein expression (using indirect immunofluorescent staining and Western immunoblot detection) and their physiological responsiveness to agonists implicated in inflammatory airway diseases, such as histamine, leukotrienes, bradykinin, platelet-activating factor (PAF), substance P (SP), thromboxane analogues and carbachol $[20,38]$. Functional coupling of $\beta_{2}$-adrenergic receptors has also been demonstrated in explant [39, 40] and enzyme-dissociated [41] primary cultures of human airway smooth muscle cells. Recent studies have demonstrated that airway smooth muscle cells cultured from a variety of species in addition to human also retain many other functionally-coupled receptors, although there are some differences in the receptors expressed in cultured cells compared to the intact muscle or freshly dispersed cell. WIDDOP et al. [47], for example, have recently reported that although cultured and acutely dissociated human airway smooth muscle cells express functional $\mathrm{M}_{2}$ and $\mathrm{M}_{3}$ muscarinic cholinergic receptors, expression of $\mathrm{M}_{3}$ receptors is much less in the cultured cells, confirming a preliminary report by MAK et al. [48]. Attempts to upregulate this receptor by WIDDOP et al. [47] were unsuccessful. Other functionally coupled receptors expressed in cultures of airway smooth muscle include: histamine, $\mathrm{H}_{1}$ [49] and $\mathrm{H}_{2}$ receptors [50]; bradykinin, $\mathrm{B}_{2}[29,36,51]$ and $\mathrm{B}_{3}$ receptors [37]; endothelin, $\mathrm{ET}_{\mathrm{A}}$ receptor ([52, 53], and Hirst unpublished observations); 5-hydroxytryptamine, 5- $\mathrm{HT}_{2}$ receptor [54]; platelet-derived growth factor type $\alpha$ and $\beta$-receptors [55]; and tumour necrosis factor- $\alpha$ p55 and p75 receptors [56]. Clearly, cultured airway smooth muscle cells are responsive to many other agonists, but direct evidence implicating the appropriate receptor(s) for each agonist is not always available.

Recent work in our own laboratory and by others suggests that as well as receptors, smooth muscle cells cultured from rabbit trachealis and human small bronchus also continue to express ion channels, particularly from the voltage-gated potassium channel family [57]. They appear to share many of the biophysical and pharmacological properties of the channels present in acutely dissociated cells from intact tissue, and are conserved even during late passage (Snetkov and Hirst, unpublished observations), suggesting that these cells in culture could represent a useful experimental system for examining the expression and behaviour of ion channels in the airways, although the culture conditions should be rigorously defined, since the nature of these channels may be influenced by the proliferative state [58].

\section{Airway smooth muscle phenotype plasticity: potential role in airway remodelling}

The ability of smooth muscle cells in culture to contract or relax in response to specific agonists is welldocumented [23, 24]. Airway smooth muscle cells in culture are no exception to this. AvNer et al. [17] reported that subconfluent primary cultures of canine tracheal smooth muscle cells contracted in response to the cholinomimetic, carbachol. Contraction, however, in cultured smooth muscle cells is dependent upon a number of carefully controlled cell culture conditions - specifically, avoidance of foetal calf serum exposure and a requirement for heparin [59]. Observations such as these have identified a link between the contractile function of smooth muscle in culture and the cellular phenotype expressed. The importance of changes in airway smooth muscle phenotype and its relationship to the control of contractility and proliferation, particularly in airway disease, is still largely overlooked, despite being the subject of intense study by vascular biologists $[60,61]$.

\section{Identifying smooth muscle phenotype in culture}

Smooth muscle cells, enzyme-dissociated into single cells and seeded into primary culture, attach and flatten on the culture substratum within 24-48 h, during which they closely resemble cells in situ [23]; i.e. substantial bundles of thick and thin filaments can easily be recognized using low power electron microscopy, there is intense immunostaining for smooth muscle-specific contractile proteins $[24,46]$, and the majority of cells visibly contract in response to spasmogens and are mitogenically quiescent [24]. Under these conditions, cells are described as being in the "contractile" phenotype. In the continued presence of growth-promoting stimuli, such as foetal calf serum, sparsely seeded contractile smooth muscle cells in culture undergo a number of spontaneous changes in phenotype over a period of a week or so, depending on the species, to what is termed as the "synthetic" phenotype. This is characterized by increased mitogenic activity and expression of intracellular organelles associated with synthesis, such as Golgi cisternae, ribosomes and rough endoplasmic reticulum (fig. 1D), and the gap junction protein, connexin43 [62]. There is also a simultaneous decrease in the intensity of immunostaining for smooth muscle-specific contractile proteins [46], although the total amount of actin and myosin remains relatively unaltered due to the accumulation of non-muscle isoforms [24, 46]. At confluence, however, the majority of smooth muscle cells re-express contractile proteins as in the original contractile phenotype. The function of the contractile phenotype is to constrict and maintain tension, whereas the function of more synthetic cells is dedicated to the synthesis and deposition of extracellular matrix components, as well as production of paracrine and autocrine growth-promoting factors [24].

The extent of reversibility of these phenotypic changes at confluence appears to be dependent upon on the initial seeding density [63]. Cells in culture that are seeded at a high density and, thus, undergo relatively few population doublings before achieving confluence, re-express the contractile phenotype and are termed "reversibly synthetic". Sparsely seeded cells, which must undergo more 
population doublings to reach confluence, are less likely to return to the contractile phenotype and are said to be "irreversibly synthetic". During increasing passage number, particularly in late passage, smooth muscle cells become increasingly irreversibly synthetic. This may also be related to differences in seeding efficiencies, where low seeding efficiencies at subculture tend to select cells which are able to begin proliferation after a shorter time in culture. Put simply, it may be that synthetic smooth muscle cells adhere more quickly than the contractile phenotype as they contain fewer myofibrils, which restrict cell spreading and attachment. Consequently, over successive passages the population of cells will become increasingly noncontractile [24]. The possible pathophysiological relevance of an irreversible synthetic smooth muscle cell phenotype is unclear. It is generally considered to be an artifact of the cell culture environment and unrelated to any process which may occur in vivo, such as a response to repeated mitogenic insults by inflammatory mediators, cytokines and growth factors. Alternatively, studies of reversible smooth muscle cell phenotype modulation in vitro have led to the hypothesis that the phenomenon of phenotype plasticity is not simply an artifact of cell culture, and that smooth muscle cells in vivo express a range of phenotypes. Indeed, several studies have confirmed that arterial smooth muscle cells undego a reversible dedifferentiation from a contractile to synthetic phenotype capable of migration, proliferation and production of synthetic phenotype-promoting matrix molecules (e.g. fibronectin), in human atheroma [64] and during the repair process following balloon catheter endothelial denudation and arterial injury [65].

Currently, there are few, if any, reports detailing the occurrence and significance of phenotypic modulation of airway smooth muscle during the development of remodelling processes in the chronically inflamed airway. Identification of reliable smooth muscle-specific molecules expressed during either the contractile or synthetic phenotypic state will undoubtedly facilitate such studies. Indeed, the need for phenotypic markers in evaluating smooth muscle dedifferentiation in asthma is now beginning to be addressed. Using Western immunoblot analysis of canine tracheal smooth muscle cells in culture, Halayko and StePhens [66] have examined the relative distribution of a number of contractile (e.g. smooth muscle myosin heavy chain, smooth muscle $\alpha$-actin), cytoskeletal (e.g. non-muscle myosin heavy chain, vimentin, desmin) and regulatory proteins (e.g. tropomyosin, calponin, caldesmon, myosin light chain kinase, protein kinase C) under nonproliferating (i.e. contractile phenotype) and proliferating (i.e. synthetic phenotype) conditions. The intermediate filament protein, vimentin was highly expressed in synthetic proliferating tracheal smooth muscle cells, consistent with the immunohistological findings of ToMMoy et al. [18]. In nondividing, contractile tracheal smooth muscle cells, smooth muscle myosin heavy chain and $\alpha$-actin were highly expressed. In vascular studies, SHANAHAN et al. [67] have reported increased gene expression for osteopontin and the matrix G1a protein associated with the synthetic state. Similar studies examining gene expression using in situ hybridization techniques in the lungs of patients with a history of severe asthma are needed to address the role of smooth muscle phenotype modulation and distribution during airway wall remodelling.
Our own studies using cultures of human and rabbit airway smooth muscle cells suggest that even during prolonged culture marked changes in morphology and in specific intracellular element (phosphorus and potassium) distributions occur in serum-starved, nondividing cells, compared to proliferating cells stimulated by foetal calf serum [44]. Similarly, the excitability of airway smooth muscle cells may be governed by phenotype. Electrophysiological studies of voltage-gated potassium channels in early passage proliferating (i.e. synthetic phenotype) human bronchial smooth muscle cells have revealed a large potassium channel (approximately 210 $\mathrm{pS}$ conductance), which could only be recorded after extreme depolarization or at elevated intracellular calcium ion concentrations. After growth arrest, however, these cells revealed an additional channel (approximately $120 \mathrm{pS}$ conductance) which was active even during moderate depolarization and at relatively low physiological intracellular calcium ion concentrations [58]. Extrapolation of these findings to the intact airway imply that airway smooth muscle possessing a greater component of cells towards the synthetic phenotype, for example during remodelling, may be less able to rectify on depolarization and, therefore, more excitable, compared to the contractile phenotype counterparts.

Smooth muscle cells either in situ or in culture should not, however, be considered exclusively contractile or synthetic. It is more likely that the contractile or synthetic state of any single cell represents a balance of features common to both phenotypes. Thus, some smooth muscle cells, whilst still contractile, will also be capable of dividing [68]. This is probably reflected in the data reported by HALAYKO and STEPHENS [66], where clear qualitative changes in protein expression between differing phenotypic states were not always readily apparent. Identification of a single phenotypic marker is, therefore, unlikely, necessitating a diverse pattern of markers to create a profile of protein expression more characteristic of one end of the phenotypic spectrum than the other.

\section{Regulation of smooth muscle function by the extracellu- lar matrix}

Studies of vascular smooth muscle as well as lung fibroblast cells in culture clearly show that phenotypic expression, in addition to its modulation by cell-derived soluble growth factors and cytokines (e.g. insulin-like growth factor-1 (IGF-1), platelet-derived growth factor (PDGF), interleukin-1 $\beta$ (IL-1 $\beta)$ ), is also influenced by components of the surrounding extracellular matrix (table 2). Latent factors (e.g. basic fibroblast growth factor (bFGF), heparin-bound epidermal growth factor (EGF) and transforming growth factor- $\beta$ (TGF- $\beta$ ), bound to the extracellular matrix and released as a result of enzymemediated (e.g. mast cell heparinases) cell-matrix interactions, can also influence smooth muscle phenotype [60, 89]. Similarly, several structural components of the extracellular matrix itself are known to modulate smooth muscle phenotype. For example, matrix molecules, such as collagen type IV, elastin, heparin and laminin, promote the contractile phenotype. Whereas, other matrix components, such as fibronectin, thrombospondin and collagen type I, promote the transition of contractile smooth 
Table 2. - Promoters and inhibitors of airway smooth muscle mitogenesis

\begin{tabular}{|c|c|c|c|c|}
\hline Factor & Source & Effect on mitogenesis & Species & {$[\operatorname{Ref}]$} \\
\hline \multicolumn{5}{|c|}{ Growth factor/cytokine } \\
\hline EGF & Ep, $\mathrm{P}$ & + & Human & {$[41,69]$} \\
\hline \multirow[t]{2}{*}{ bFGF } & ECM, M $\theta$, SMC & + & Bovine & [70] \\
\hline & & + & Human & Hirst ${ }^{\#}$ \\
\hline \multirow[t]{2}{*}{ PDGF } & $\mathrm{P}, \mathrm{M} \theta, \mathrm{SMC}, \mathrm{Ep}$ & + & Rabbit & {$[71]$} \\
\hline & & + & Human & {$[55,71]$} \\
\hline \multirow[t]{2}{*}{ IGF-1 } & $\mathrm{P}, \mathrm{M} \theta, \mathrm{SMC}$ & + & Bovine & {$[70]$} \\
\hline & & + & Rabbit & {$[72]$} \\
\hline IL- $1 \beta$ & $\mathrm{T}, \mathrm{M} \theta, \mathrm{SMC}, \mathrm{Ep}$ & + & Guinea-pig & {$[35,73]$} \\
\hline IL-6 & $\mathrm{T}, \mathrm{M} \theta, \mathrm{SMC}, \mathrm{Ep}$ & + & Guinea-pig & {$[73]$} \\
\hline \multirow[t]{2}{*}{ Thrombin } & $\mathrm{Pl}$ & + & Rabbit & {$[34]$} \\
\hline & & + & Human & {$[41,75]$} \\
\hline TNF- $\alpha$ & $\mathrm{T}, \mathrm{M} \theta, \mathrm{SMC}, \mathrm{Ep}$ & \pm & Human & {$[74,76]$} \\
\hline TGF- $\beta$ & $\mathrm{M} \theta, \mathrm{P}, \mathrm{ECM}, \mathrm{T}$ & \pm & Bovine & {$[77]$} \\
\hline \multicolumn{5}{|c|}{ Inflammatory mediators } \\
\hline \multirow[t]{2}{*}{ Histamine } & M & + & Canine & {$[27]$} \\
\hline & & + & Human & {$[78]$} \\
\hline \multirow[t]{3}{*}{ Endothelin-1 } & $\mathrm{P}, \mathrm{M} \theta, \mathrm{Ep}, \mathrm{Pl}$ & + & Rabbit & {$[33]$} \\
\hline & & + & Ovine & [79] \\
\hline & & + & Human & {$[80]$} \\
\hline 5-HT & $\mathrm{P}, \mathrm{Pl}$ & + & Rabbit & Hirst $^{\#}$ \\
\hline Substance P & Neuronal, Ep & + & Rabbit & [81] \\
\hline VIP & Neuronal & - & Human & {$[82]$} \\
\hline $\mathrm{PGE}_{2}$ & Ep, SMC & - & Guinea-pig & [83] \\
\hline \multicolumn{5}{|l|}{ Enzymes } \\
\hline Tryptase & M & + & Canine & {$[84]$} \\
\hline$\beta$-Hexosaminidase & M & + & Bovine & {$[30]$} \\
\hline Lysosomal hydrolases & M & + & Canine & [85] \\
\hline \multicolumn{5}{|l|}{ Matrix } \\
\hline \multirow[t]{3}{*}{ Heparin } & M, ECM & - & Human & {$[86]$} \\
\hline & & - & Canine & {$[87]$} \\
\hline & & - & Bovine & {$[88]$} \\
\hline
\end{tabular}

\#: Hirst unpublished. EGF: epidermal growth factor; bFGF: basic fibroblast growth factor; PDGF: platelet-derived growth factor; IGF-1: insulin-like growth factor-1; IL: interleukin; TNF- $\alpha$ : tumour necrosis factor- $\alpha$; TGF- $\beta$ : transforming growth factor- $\beta$; 5-HT: serotonin (5-hydroxytryptamine); VIP: vasoactive intestinal peptide; PGE $_{2}$ : prostaglandin $\mathrm{E}_{2}$. M: mast cell; P: platelet; M $\theta$ : macrophage/monocyte; Ep: epithelial cell; Pl: plasma; SMC: smooth muscle cell; ECM: extracellular matrix;

T: T-lymphocyte. +: stimulant; -: inhibitor; \pm : both stimulant and inhibitor, depending on conditions.

muscle cells to the synthetic phenotype [90-92]. Significantly, under these conditions, the smooth muscle cell itself can also synthesize many of these matrix molecules [93], and so alter the matrix composition and promote the synthetic phenotype and gene expression for growth factors and their receptors in adjacent smooth muscle cells [94]. In atherosclerosis, the synthetic activity of phenotypically altered smooth muscle cells appears to be central in determining the matrix composition of the lesion, with the smooth muscle cell being solely responsible for its synthesis [60]. Ultimately, this results in an altered capacity of these cells to respond to vasospastic agents, mitogens and chemoattractants. Expression and deposition of extracellular matrix components which promote the synthetic phenotype in smooth muscle cultures, such as collagens I and III and fibronectin, has also been shown to be upregulated by macrophage-derived cytokines, such as IL- $1 \beta$, PDGF and TGF- $\beta$, the latter being the most potent [95]. Interestingly, the transition to the synthetic phenotype stimulated by these cytokines was inhibited by the $\mathrm{Th}_{1}$ cell cytokine, interferon (IFN) $-\gamma$.
Clearly, by analogy, smooth muscle cells from the airways, in addition to their bronchospastic function, may also constitute a source of growth factors, cytokines and extracellular matrix products capable of inducing a greater proportion of synthetic phenotype smooth muscle cells within the airway wall, as well as recruiting inflammatory cells and perpetuating the severity of the inflammation (fig. 2). Although studies of this nature, implicating a central role for smooth muscle in matrix production and phenotype modulation in airway wall remodelling during severe inflammation have not yet been reported, there is evidence from histological studies to support such a hypothesis. Fibronectin and collagen deposition (particularly type III, together with types I and V) as well as "myofibroblast" proliferation is thought to contribute to subepithelial fibrosis in the bronchi of asthmatics [96]. RocHE and co-workers [97, 98] have suggested that it is the myofibroblast which is responsible for collagen deposition and basement membrane thickening in bronchial asthma. Although there is some debate as to the origin of the myofibroblast [99], it is possible to speculate that 


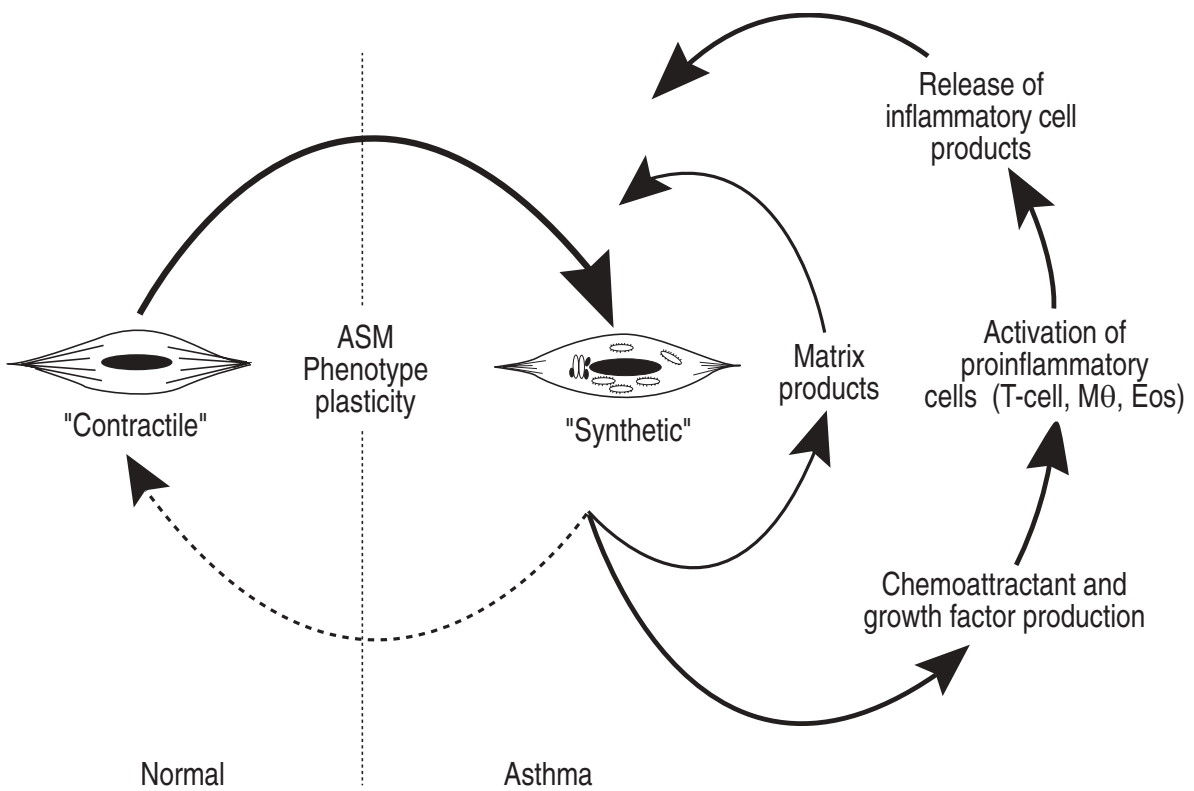

Fig. 2. - Schematic summary of some of the possible inflammatory loop mechanisms which may destabilize airway smooth muscle (ASM) contractile phenotype towards the synthetic state, exacerbating the persistent nature of the underlying pathology of chronic asthma. Repeated inflammatory insults, involving the action of growth factors, cytokines and other mediators, may promote changes in airway smooth muscle phenotype leading to its increased synthetic function and mitogenesis. The subsequent production of proinflammatory factors and matrix components by synthetic phenotype smooth muscle cells could promote similar changes in neighbouring contractile smooth muscle cells as well as promoting further infiltration of inflammatory cells. The net result would be a greater proportion of the synthetic phenotype of smooth muscle cells present in the airway wall, as well as increased infiltration of inflammatory cells, and perpetuation of the inflammation. T-cell: T-lymphocyte; M $\theta$ : macrophage/monocyte; Eos: eosinophil.

these "myofibroblasts" are phenotypically derived from airway smooth muscle cells, perhaps in the guise of the synthetic phenotype. Moreover, the production of collagen type I and fibronectin by these myofibroblasts may be under the control of activated bronchial epithelial cells [100]. Epithelial cell shedding, a characteristic finding in the airways of even mild asthmatics [101-103], could, therefore, result in marked changes in the matrix composition and in turn promote changes in myofibroblast/smooth muscle phenotype.

A recent study in nonobstructed human airways has identified the presence of tenascin (also known as neuronectin or hexabrachion), a newly discovered matrix element, just below the epithelium of proximal airway [104]. Tenascin is usually expressed in the extracellular matrix of mesenchymal tissues undergoing rapid changes, for example, during neonatal tissue development and tumorigenesis [105]. In adults, its expression is restricted to tissue growth and reorganization, for example during tissue repair and remodelling processes [105], including atherosclerosis and animal models of arterial injury [106]. In vascular remodelling, the synthetic smooth muscle cell has been proposed as a source of tenascin [106]. Its function is thought to be antiadhesive leading to cell rounding and partial detachment from the substratum [105] - a prerequisite for cell migration and mitogenesis and directly correlated with the number and distribution of focal adhesions at the cell surface. Its role in epithelial shedding during airway inflammation in asthma has not been reported.

The receptors mediating focal adhesions of the cell surface to matrix molecules (as well as to other cells) belong to the "integrin" family of proteins and glycoproteins. Integrin receptors are linked to tyrosine phosphorylation by activation of focal adhesion kinases. The integrin receptor subunit, $\alpha_{9}$, which when combined as a heterodimer with another subunit, $\beta_{1}$, binds tenascin, is expressed throughout the airway epithelium [104]. Similarly, human bronchial epithelial cells when placed in culture, express the $\alpha_{v} \beta_{6}$ complex, which binds both fibronectin and tenascin [104]. In a recent study, LAZAAR et al. [107] described other relatives of the adhesion molecule family present on human cultured airway smooth muscle cells. These authors reported that tumour necrosis factor- $\alpha$ induced expression of the intercellular adhesion molecule-1 (ICAM-1), a counter-receptor binding protein for the lymphocyte function antigen-1 $\beta$ integrin. In the same study, activated T-lymphocytes adhered to, and stimulated deoxyribonucleic acid (DNA) synthesis in cultures of human airway smooth muscle [107]. This interaction was mediated, in part, by cytokine-inducible ICAM-1, suggesting that cell adhesion molecule-mediated T-lymphocyte adhesion may be partly responsible for smooth muscle growth in vivo and, thereby, contribute to the remodelling that occurs in persistent asthma. Confirmation of altered smooth muscle phenotype as a result of these events was not described.

In conclusion, in this review, an attempt has been made to outline the potential role that bronchial wall smooth muscle may play in the airway wall chronic remodelling process, characteristic of poorly reversible airway obstruction. Cell culture of smooth muscle from the airways offers an invaluable experimental model with which to investigate some of the longer-term molecular and cellular events associated with these changes. Such studies are only just beginning to emerge. Studies of vascular smooth muscle cells in culture have provided new insights into the nature of smooth muscle function in disease, and have led to the recognition and characterization of multiple phenotypes present not only in 
culture but also during human vascular disease, illustrating the remarkable structural and functional plasticity of smooth muscle which enables it to develop an adaptive response to altered environmental conditions. The occurrence of multiple phenotypes of smooth muscle having differing properties or functions within the airway wall in vivo, which could be isolated and grown in primary culture and subsequently cloned, has also not been investigated. Similarly, the implication that airway smooth muscle phenotype stability, and therefore its function within the inflamed airway wall, may be dependent on the milieu created not only by inflammatory cell products but also by changes in the composition of the surrounding extracellular matrix, brought about by the smooth muscle itself, warrants investigation.

Structural remodelling as a result of repeated inflammatory insults, leading to increased mural smooth muscle content and irreversible airflow obstruction, could be the result of several concurrent process which become increasingly influenced by altered airway smooth muscle phenotype as the pathology matures. These processes include changes in smooth muscle phenotype, and therefore responsiveness, as well as proliferation, synthesis of extracellular matrix components and autocrine production of growth factors, in turn perpetuating the chronicity of the disease process. Cell culture techniques offer a strong starting position for evaluating a potential role of the airway smooth muscle cell as a common denominator in orchestrating these processes.

Acknowledgement: The author thanks the Wellcome Trust (\#039419) for their support.

\section{References}

1. Barnes PJ. Inflammation. In: Weiss EB, Stein M, eds Bronchial Asthma: Mechanisms and Therapeutics. 3rd edn. Boston, Little Brown \& Co, 1993; pp. 80-94.

2. Djukanovic R, Roche WR, Wilson JW, et al. Mucosal inflammation in asthma. Am Rev Respir Dis 1990; 142: 434-457.

3. Dunnill MS, Masserella GR, Anderson JA. A comparison of the quantitative anatomy of the bronchi in normal subjects, in status asthmaticus, in chronic bronchitis and in emphysema. Thorax 1969; 24: 176-179.

4. Heard BE, Hossain S. Hyperplasia of bronchial muscle in asthma. J Pathol 1973; 110: 319-331.

5. Hossain S. Quantitative measurement of bronchial muscle in men with asthma. Am Rev Respir Dis 1973; 107: 99-109.

6. Ebina M, Yaegashi H, Chibo R, Takahashi T, Motomiya M, Tanemura M. Hyperreactive site in the airway tree of asthmatic patients revealed by thickening of bronchial muscles. Am Rev Respir Dis 1990; 141: 1327-1332.

7. Jeffrey PK. Pathology of asthma. Br Med Bull 1992; 48: 23-39.

8. Brown JP, Breville WH, Finucane KE. Asthma and irreversible airflow obstruction. Thorax 1984; 39: 131-136.

9. Juniper EF, Kline PA, Vanieleghem MA, Ramsdale EH, O'Byrne PM, Hargreave FE. Effect of long-term treatment with an inhaled corticosteroid (budesonide) on airway hyperresponsiveness and clinical asthma in nonsteroid-dependent asthmatics. Am Rev Respir Dis 1990; 142: 832-836.
10. James AL, Hogg JC, Dunn LA, Pare PD. The use of internal perimeter to compare airway size and to calculate smooth muscle shortening. Am Rev Respir Dis 1988; 139: 136-139.

11. James AL, Pare PD, Hogg JC. The mechanics of airway narrowing in asthma. Am Rev Respir Dis 1989; 139: 242-246.

12. Pare PD, Wiggs BR, Hogg JC, Bosken C. The comparative mechanics and morphology of airways in asthma and in chronic obstructive pulmonary disease. Am Rev Respir Dis 1991; 143: 1189-1193.

13. Lambert RK, Wiggs BR, Kuwano K, Hogg JC, Pare PD. Functional significance of increased airway smooth muscle in asthma and COPD. J Appl Physiol 1993; 74: 2771-2781.

14. Bramley AM, Thomson RJ, Roberts CR, Schellenberg RR. Excessive bronchoconstriction in asthma is due to decreased airway elastance. Eur Respir J 1994; 7: 337-341.

15. Ebina M, Takahashi T, Chiba T, Motomiya M. Cellular hypertrophy and hyperplasia of airway smooth muscle underlying bronchial asthma. Am Rev Respir Dis 1993; 148: 720-726.

16. Pare PD, Bai TR. The consequences of chronic allergic inflammation. Thorax 1995; 50: 328-332.

17. Avner BP, DeLongo J, Wilson S, Ladman AJ. A method for culturing canine tracheal smooth muscle cells in vitro: morphological and pharmacological observations. Anat Rec 1981; 200: 357-370.

18. Tom-Moy M, Madison JM, Jones CA, DeLanerolle P, Brown JK. Morphological characterisation of cultured smooth muscle cells isolated from the tracheas of adult dogs. Anat Rec 1987; 218: 313-328.

19. Twort CHC, van Breemen C. Human airway smooth muscle in culture. Tissue Cell 1988; 20: 339-344.

20. Panettieri RA, Murray RK, DePalo LR, Yadvish PA, Kotlikoff MI. A human airway smooth muscle cell line that retains physiological responsiveness. Am J Physiol 1989; 256: C329-C335.

21. Carroll N, Elliot J, Morton A, James A. The structure of large and small airways in nonfatal and fatal asthma. Am Rev Respir Dis 1993; 147: 405-410.

22. Holgate S. Mediator and cytokine mechanisms in asthma. Thorax 1993; 48: 103-109.

23. Chamley-Campbell J, Campbell G, Ross R. The smooth muscle cell in culture. Physiol Rev 1979; 59: 1-61.

24. Campbell JH, Campbell GR. Culture techniques and their applications to studies of vascular smooth muscle. Clin Sci 1993; 85: 501-513.

25. Thyberg J, Nilsson J, Palmberg L, Sjolund M. Adult human arterial smooth muscle cells in primary culture: modulation from contractile to synthetic phenotype. Cell Tissue Res 1985; 239: 69-75.

26. Gabella G. Structure of smooth muscles. In: Bulbring E, Brading AF, Jones AW, Tomita T, eds. Smooth Muscle: An Assessment of Current Knowledge. Austin, University of Texas Press, 1981; pp. 1-20.

27. Panettieri RA, Yadvish PA, Kelly AM, Rubinstein NA, Kotlikoff MI. Histamine stimulates proliferation of airway smooth muscle and induces c-fos expression. Am J Physiol 1990; 259: L365-L371.

28. Yang CM, Chou S-P. Primary culture of canine tracheal smooth muscle cells in serum-free medium: effects of insulin-like growth factor-1 and insulin. J Receptor Res 1993; 13: 943-960.

29. Marsh KA, Hill SJ. Bradykinin $\mathrm{B}_{2}$ receptor-mediated phosphoinositide hydrolysis in bovine cultured tracheal smooth muscle cells. Br J Pharmacol 1192; 107: 443-447. 
30. Lew DB, Nebigil C, Malik KU. Dual regulation of cAMP of $\beta$-hexosaminidase-induced mitogenesis in bovine tracheal myocytes. Am J Respir Cell Mol Biol 1992; 7: 614-619.

31. Delamere F, Holland E, Patel S, Bennett J, Pavord I, Knox A. Production of $\mathrm{PGE}_{2}$ by bovine cultured airway smooth muscle cells and its inhibition by cyclooxygenase. Br J Pharmacol 1994; 111: 983-988.

32. Hirst SJ, Barnes PJ, Twort CHC. Quantifying proliferation of cultured human and rabbit airway smooth muscle in response to serum and platelet-derived growth factor. Am J Respir Cell Mol Biol 1992; 7: 574-581.

33. Noveral JP, Rosenberg SM, Anbar RA, Pawlowski NA, Grunstein MM. Role of endothelin-1 in regulating proliferation of cultured rabbit airway smooth muscle cells. Am J Physiol 1992; 263: L317-L324.

34. Noveral JP, Grunstein, MM. Role and mechanism of thromboxane-induced proliferation of cultured airway smooth muscle cells. Am J Physiol 1992; 263: L555-L561.

35. De S, Zelazny ET, Souhrada JF, Souhrada M. Interleukin$1 \beta$ stimulates the proliferation of cultured airway smooth muscle cells via platelet-derived growth factor. Am J Respir Cell Mol Biol 1993; 9: 645-651.

36. Pyne S, Pyne NJ. Bradykinin stimulates phospholipase $\mathrm{D}$ in primary cultures of guinea-pig tracheal smooth muscle. Biochem Pharmacol 1993; 45: 595-603.

37. Farmer SG, Ensore JE, Burch RM. Evidence that cultured airway smooth muscle cells contain bradykinin $\mathrm{B}_{2}$ and $\mathrm{B}_{3}$ receptors. Am J Respir Cell Mol Biol 1991; 4: 273-277.

38. Twort CHC, van Breemen C. Human airway smooth muscle in culture: control of the intracellular calcium store. Pulm Pharmacol 1989; 2: 45-53.

39. Hall IP, Widdop S, Townsend P, Daykin K. Control of cyclic AMP content in primary cultures of human airway smooth muscle cells. Br J Pharmacol 1992; 107: 422-428.

40. Hall IP, Daykin K, Widdop S. $\beta_{2}$-adrenoceptor desensitisation in cultured human airway smooth muscle. Clin Sci 1993; 84: 151-157.

41. Tomlinson PR, Wilson JW, Stewart AG. Inhibition by salbutamol of the proliferation of human airway smooth muscle cells grown in culture. Br J Pharmacol 1994; $111,641-647$.

42. Snetkov VA, Hirst SJ, Twort CHC, Ward JPT. Potassium currents in human freshly isolated bronchial smooth muscle cells. Br J Pharmacol 1995; 115: 1117-1125.

43. Warley A, Cracknell KPB, Cammish HB, Twort CHC, Ward JPT, Hirst SJ. Preparation of cultured airway smooth muscle cells for study of intracellular element concentrations by X-ray microanalysis: comparison of whole cell mounts with cryosections. J Microscopy 1994; 175: 143-153.

44. Warley A, Hirst SJ, Twort CHC, Ward JPT. Changes in element content and morphology of rabbit cultured tracheal smooth muscle cells after stimulation with fetal calf serum. Am J Respir Crit Care Med 1994: 149: A302.

45. Gown AM, Vogel AN, Gordon D, Lu PL. A smooth muscle-specific monoclonal antibody recognises smooth muscle actin isozymes. J Cell Biol 1985; 100: 807-813.

46. Owens GK, Loeb A, Gordon D, Thompson MM. Expression of smooth muscle-specific $\alpha$-isoactin in cultured vascular smooth muscle cells: a relationship between growth and cytodifferentiation. J Cell Biol 1986; 102: 343-352.

47. Widdop S, Daykin K, Hall IP. Expression of muscarinic $\mathrm{M}_{2}$ receptors in cultured human airway smooth muscle cells. Am J Respir Cell Mol Biol 1993; 9: 541-546.
48. Mak JC, Baraniuk JN, Barnes PJ. Localisation of muscarinic receptor subtype mRNAs in human lung. Am J Respir Cell Mol Biol 1992; 7: 344-348.

49. Daykin K, Widdop S, Hall IP. Control of histamineinduced inositol phospholipid hydrolysis in human tracheal smooth muscle cells. Eur J Pharmacol 1993; 246: 135-140.

50. Florio C, Flezar M, Martin JG, Heisler S. Identification of adenylate cyclase-coupled histamine $\mathrm{H}_{2}$ receptors in guinea-pig tracheal smooth muscle cells in culture and the effect of dexamethasone. Am J Respir Cell Mol Biol 1992; 7: 582-589.

51. Yang CM, Hsai H-C, Chou S-P, Ong R, Luo S-F. Bradykinin-stimulated phosphoinositide metabolism in cultured canine tracheal smooth muscle cells. Br J Pharmacol 1994; 111: 21-28.

52. Yang CM, Yo Y-L, Ong R, Hsai H-C. Endothelin- and sarafotoxin-induced phosphoinositide hydrolysis in cultured canine tracheal smooth muscle cells. J Neurochem 1994; 62: 1440-1448.

53. Stewart AG, Tomlinson PR, Wilson J. Airway wall remodelling in asthma: a novel therapeutic target for the development of anti-asthma drugs. Trends Pharmacol Sci 1993; 14: 275-279.

54. Yang CM, Yo Y-L, Hsai H-C, Ong R. 5-Hydroxytryptamine receptor-mediated phosphoinositide hydrolysis in canine cultured tracheal smooth muscle cells. $\mathrm{Br} J$ Pharmacol 1994; 111: 777-786.

55. Hirst SJ, Barnes PJ, Twort CHC. PDGF receptor expression and differential proliferation induced by PDGF isoforms in human cultured bronchial smooth muscle cells. Am J Physiol 1995; (in press).

56. Amrani Y, Frossard N, Landry Y, Bronner C. Tumor necrosis factor alpha (TNF- $\alpha$ ) modulates intracellular calcium homeostasis and induces proliferation of cultured human tracheal smooth muscle. Am J Respir Crit Care Med 1995; 151: A46.

57. Snetkov VA, Hirst SJ, Twort CHC, Ward JPT. Potassium currents in human bronchial and rabbit tracheal smooth muscle cells in culture. Am J Respir Crit Care Med 1994; 149: A1082.

58. Snetkov VA, Hirst SJ, Twort CHC, Ward JPT. Alterations to large conductance $\mathrm{K}^{+}$currents during proliferation in human bronchial smooth muscle cells. Am J Respir Crit Care Med 1995; 151: A49.

59. Bowers CW, Dahm LM. Maintenance of contractility in dissociated smooth muscle: low density cultures in a defined medium. Am J Physiol 1993; 264: C229-C236.

60. Raines EW, Ross R. Smooth muscle cells and the pathogenesis of the lesions of atherosclerosis. Br Heart $J$ 1993; 69 (Suppl.): S30-S37.

61. Sartore S, Scatena M, Chiavegato A, Faggin E, Giuriato L, Pauletto P. Myosin isoform expression in smooth muscle cells during physiological and pathological vascular remodelling. J Vasc Res 1994; 31: 61-81.

62. Rennick RE, Connat J-L, Burnstock G, Rothery S, Severs NJ, Green CR. Expression of connexin43 gap junctions between cultured vascular smooth muscle cells is dependent upon phenotype. Cell Tissue Res 1993; 271: 323-332.

63. Campbell JH, Kocher O, Skalli O, Gabbiani G, Campbell GR. Cytodifferentiation and expression of alpha-smooth muscle actin mRNA and protein during primary culture of aortic smooth muscle cells: correlation with cell density and proliferative state. Arteriosclerosis 1989; 9: 633-643.

64. Babaev VR, Bobryshev YV, Stenina OV, Tararak EM, Gabbiani G. Heterogeneity of smooth muscle cells in 
atheromatous plaque of human aorta. Am J Pathol 1990; 136: 1031-1042.

65. Okamoto E, Imataka K, Fujii J, et al. Heterogeneity in smooth muscle cell populations in neointimas and the media of post-stenotic dilatation of rabbit carotid artery. Biochem Biophys Res Commun 1992; 185: 459-464.

66. Halayko A, Stephens NL. Potential role for phenotypic modulation of bronchial smooth muscle cells in chronic asthma. Can J Physiol Pharmacol 1994; 72: 1448-1457.

67. Shanahan CM, Weissberg PL, Metcalfe JH. Phenotypic markers of differentiated and proliferating vascular smooth muscle cells. Circ Res 1993; 73: 193-204.

68. Campbell, JH, Campbell, GR. Mitosis of contractile smooth muscle cells in tissue culture. Exp Cell Res 1974; 84: 105.

69. Panettieri RA, Rubinstein NA, Feuerstein B, Kotlikoff MI. Beta-adrenergic inhibition of airway smooth muscle proliferation. Am Rev Respir Dis 1991; 143: A608.

70. Kelleher MD, Schneider SD, Naureckas ET, et al. Responsiveness of bovine tracheal smooth muscle cells to various mitogens. Am J Respir Crit Care Med 1994; 149: A304.

71. Hirst SJ, Barnes PJ, Twort CHC. Proliferation of human and rabbit airway smooth muscle in culture by plateletderived growth factor isoforms. Am J Respir Crit Care Med 1994; 149: A302.

72. Noveral JP, Bhala A, Hintz RL, Grunstein MM, Cohen P. Insulin-like growth factor axis in airway smooth muscle cells. Am J Physiol 1994; 267: L761-L765.

73. De S, Zelazny ET, Souhrada JF, Souhrada M. Interleukin$1 \beta$ and interleukin-6 induce both hyperplasia and hypertrophy of cultured guinea-pig airway smooth muscle cells. Am J Respir Crit Care Med 1994; 149: A707.

74. Stewart AG, Tomlinson PR, Wilson JW, Dadley-Moore $\mathrm{D}$, Harris T. Tumor necrosis factor- $\alpha$ has biphasic effects on the proliferation of human cultured airway smooth muscle. Am J Respir Crit Care Med 1994; 149: A304.

75. Panettieri RA, Hall IP, Murray RK. $\alpha$-Thrombin increases cytosolic calcium and induces human airway smooth muscle cell proliferation. Am J Respir Crit Care Med 1995; 151: A47.

76. Stewart AG, Tomlinson PR, Fernandes DJ, Wilson JW, Harris T. Tumor necrosis factor- $\alpha$ modulates mitogenic responses of human cultured airway smooth muscle. $A m$ J Respir Cell Mol Biol 1995; 12: 110-119.

77. Black PN, Young PG, Scott L, Merrilees MJ, Skinner SJM. Is transforming growth factor-beta an autocrine growth factor for airway smooth muscle? Am J Respir Crit Care Med 1994; 149: A302.

78. Panettieri RA, Rubinstein NA, Kelly AM, Kotlikoff MI. The specificity of c-fos expression in the induction of airway smooth muscle proliferation by contractile agonists. Am Rev Respir Dis 1991; 143: A934.

79. Glassberg MK, Ergul A, Wanner A, Puett D. Endothelin1 promotes mitogenesis in airway smooth muscle cells. Am J Respir Cell Mol Biol 1994; 10: 316-321.

80. Johnson PRA, Carey DL, Armour CL, Black JL. Endothelin-1 and platelet-derived growth factor are co-mitogenic on human airway smooth muscle cells in culture. Am J Respir Crit Care Med 1995; 151: A48.

81. Noveral JP, Grunstein MM. Tachykinin regulation of airway smooth muscle cell proliferation. Am J Respir Crit Care Med 1995; 151: A48.

82. Maruno K, Said SI. Vasoactive intestinal peptide (VIP) neutralises the mitogenic effect of thrombin on human airway smooth muscle (ASM) cells. Am J Respir Crit Care Med 1995; 151: A48.
83. Florio C, Martin JG, Styhler A, Heisler S. Antiproliferative effect of prostaglandin $\mathrm{E}_{2}$ in cultured guinea-pig tracheal smooth muscle cells. Am J Physiol 1994; 266: L131-L137.

84. Brown JK, Jones CA, Tyler CL, Ruoss SJ, Hartmann T, Caughey GH. Tryptase-induced mitogenesis in airway smooth muscle cells: potency, mechanisms and interactions with other mast cell mediators. Chest 1995; 107 (Suppl. 3): 95S-96S.

85. Lew DB, Ratazzi MC. Mitogenic effect of lysosomal hydrolase on bovine tracheal myocytes in culture. J Clin Invest 1991; 88: 1969-1975.

86. Johnson PRA, Armour CL, Carey DL, Black JL. The effect of heparin on human airway smooth muscle growth in culture. Am J Respir Crit Care Med 1994; 149: A300.

87. Halayko AJ, Delacruz R, Stephens NL. Heparin sulfate inhibits proliferation of cultured airway smooth muscle cells but does not prevent phenotype modulation. Am J Respir Crit Care Med 1994; 149: A300.

88. Kilfeather SA, Tagoe S, Perez AC, Okona-Mensa K, Matin R, Page CP. Inhibition of serum-induced proliferation of bovine tracheal smooth muscle cells by heparin and related glycosaminoglycans. Br J Pharmacol 1995; 114: 1442-1446.

89. Rubin K, Tingstrom A, Hansson GK, et al. Induction of B-type receptors for platelet-derived growth factor in vascular inflammation: possible implications for development of vascular proliferative lesions. Lancet 1988; i: 1353-1356.

90. Thyberg J, Hultgardh-Nilsson A. Fibronectin and the basement membrane components laminin and collagen type IV influence the phenotypic properties of subcultured rat aortic smooth muscle cells differently. Cell Tissue Res 1994; 276: 263-721.

91. Yamamoto M, Yamamoto K, Noumura T. Type I collagen promotes modulation of cultured rat arterial smooth muscle cells from a contractile to a synthetic phenotype. Exp Cell Res 1993; 204: 121-129.

92. Sanders M. Molecular and cellular concepts in atherosclerosis. Pharmacol Ther 1994; 61: 109-153.

93. Baskin LS, Howard PS, Duckett JW, Snyder HM, Macarek EJ. Bladder smooth muscle cells in culture. I. Identification and characterisation. J Urol 1993; 149: 190_ 197.

94. Ross R. The pathogenesis of atherosclerosis: a perspective for the 1990s. Nature 1993; 362: 801-809.

95. Amento EP, Ehsani N, Palmer H, Libby P. Cytokines and growth factors positively and negatively regulate interstitial collagen synthesis gene expression in human vascular smooth muscle cells. Arteriosclerosis Thromb 1991; 11: 1223-1230.

96. Roche WR, Beasley R, Williams JH, Holgate ST. Subepithelial fibrosis in bronchi of asthmatics. Lancet 1989; i: $520-524$.

97. Roche WR, Brewster CE, Djukanovic R, Wilson J, Howarth PH. Myofibroblasts are responsible for basement membrane thickening in bronchial asthma. Am Rev Respir Dis 1990; 141: A501.

98. Brewster CEP, Howarth PH, Djukanovic R, Wilson J, Holgate ST, Roche WR. Myofibroblasts and subepithelial fibrosis in bronchial asthma. Am J Respir Cell Mol Biol 1990; 3: 507-511.

99. Sappino AP, Schurch W, Gabbiani G. Differentiation repertoire of fibroblast cells: expression of cytoskeletal proteins as markers of phenotypic modulation. Lab Invest 1990; 63: 144-161.

100. Kawamoto M, Romberger DJ, Nakamura Y, et al. Modulation of fibroblast type I collagen and fibronectin 
production by bovine bronchial epithelial cells. Am J Respir Cell Mol Biol 1995; 12: 425-433.

101. Beasley R, Roche WR, Roberts JA, Holgate ST. Cellular events in bronchi in mild asthma and after bronchial provocation. Am Rev Respir Dis 1989; 139: 806-817.

102. Laitinen LA, Heino M, Laitinen A, Kava T, Haahtela T. Damage of the airway epithelium and bronchial respiratory tract in patients with asthma. Am Rev Respir Dis 1985; 131: 599-606.

103. Jeffrey PK, Wardlaw AJ, Nelson FC, Collins JV, Kay AB. Bronchial biopsies in asthma: an ultrastructural, quantitative study and correlation with hyperreactivity. Am Rev Respir Dis 1989; 140: 1745-1753.

104. Weinacker A, Ferrando R, Elliot M, Hogg J, Balmes J, Sheppard D. Distribution of integrins $\alpha_{v} \beta_{6}$ and $\alpha_{9} \beta_{1}$ and their known ligands, fibronectin and tenascin in human airways. Am J Respir Cell Mol Biol 1995; 12: 547-557.

105. Lightner VA, Slemp CA, Erickson HP. Localisation and quantitation of hexabrachion (tenascin) in skin, embryonic brain, tumors and plasma. Ann NY Acad Sci 1990; 580: 260-275.

106. Hedin U, Holm J, Hansson GK. Induction of tenascin in rat arterial injury: relationship to altered smooth muscle cell phenotype. Am J Pathol 1991; 139: 649-656.

107. Lazaar AL, Albelda SM, Pilewski JM, Brennan B, Pure E, Panettieri RA. T-lymphocytes adhere to airway smooth muscle via integrins and CD44 and induce smooth muscle cell DNA synthesis. J Exp Med 1994; 180: 807816. 